TAX AVOIDANCE STRATEGIES OF

MULTINATIONAL COMPANIES:

A CASE STUDY OF APPLE INC.

U Perera
Sri Lanka Journal of

Economic Research

Volume 9(1) December 2021

SLJER 09.01.04: pp. 71-87

Sri Lanka Forum of

University Economists

DOI: http://doi.org/10.4038/sljer.v9i1.156

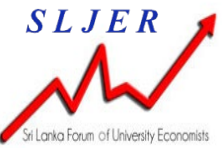

\begin{abstract}
This study concentrates on the tax avoidance strategies of multinational companies using the case study of Apple Inc. Objectives of the analysis include identifying strategies that could be exploited by multinational companies to avoid taxes and to find improvements for the Sri Lankan tax system based on the loopholes that multinational companies could exploit.

The methodology consists of a critical analysis based on literature and secondary data. Findings of the study include thin capitalization, manipulation of transfer prices and royalty payments, Double Irish Arrangement and Dutch Sandwich, tax inversion and cost sharing agreements as some of the tax avoiding strategies used by multinational companies.

Recommendations of the study applicable for the Sri Lankan context include addressing the loopholes of the tax system by implementing country-by-country reporting at least for the companies headquartered in Sri Lanka, a common reporting standard for all the companies, formulate and implement Controlled Financial Corporation rules and to limit certain incentives including tightening of foreign dividend income regulations.
\end{abstract}

Keywords: Multinational Companies, Tax, Tax Avoidance, Tax Avoidance Strategies

\title{
U Perera
}

Institute of Policy Studies of Sri Lanka

Email: ushaperera123@gmail.com Tel: +94 779031375

(iD) https://orcid.org/0000-0003-2963-0041 


\section{INTRODUCTION}

The literature discusses in detail how important it is to pay taxes to the government in a decent civil society for its own development. To redistribute wealth from rich to poor, manage negative externalities, provide public goods etc., are some of the uses of the taxes. However, present-day companies are practicing tax avoidance with extensive tax planning to reduce their effective tax rates (Rego, 2003). This has become a major issue for most countries, especially in tackling the fiscal deficits, because it is argued that tax avoidance will erode the tax base. Accordingly, this study expects to address this issue considering a multinational company as an example of how they have avoided taxes through methods like transfer pricing, royalty payments, intra-corporate loans, inversions etc (Contractor, 2016). It is essential to identify the strategies that could be exploited by the Multinational Companies (MNCs) and the loopholes of the tax system to close them to minimize tax avoidance and to improve the legal framework of a country.

It could be observed that MNCs seem to consider the world as their blank canvas (Contractor, 2016). These firms can manipulate to shift their income from higher tax bases to lower tax bases. Accordingly, most of the countries have faced the problem of tax base erosion. Thus, this has become a massive problem for most countries. Further, MNCs try to improve the Earnings Per Share (EPS) for their shareholders, so that a higher EPS will determine the success of the companies. On the other hand, if more profits after taxes are conserved, these can be used for further foreign operations and research and development functions that will determine the improved performance and higher dividends for shareholders. However, multinational companies go for high levels of foreign investments for certain countries, transfer of technology, job creation, cost reductions through production efficiency with the use of research and development activities etc. Accordingly, there is a clear conflict of interest between the companies and the governments. Thus, this conflict of interest between multinational companies and governments creates a problem that requires solutions throughout the world. Thus, it is of high importance to identify the ways that multinational companies avoid taxes to close those loopholes. Tax avoidance has become a major issue in Sri Lanka with the fiscal deficits and expanding economic activities.

Dharmarathna (2020) showed that how the best performing companies listed in the Colombo Stock Exchange (CSE) make strategies in tax planning to reduce tax liabilities using the Effective Tax Rates and the financial performance measures like Return on Assets. According to this study, the managers of best performing companies in Sri Lanka are weak in setting strategies on the corporate tax planning process. Further, it was implied that Sri Lankan firms do not efficiently utilize the loopholes embedded in the Sri Lankan tax law. However, there is limited research as to how multinational companies can exploit the loopholes in the Sri Lankan tax system to avoid taxes. Thus, this paper aims to fill the existing gap in the literature. The study aims at probing the following 
research questions. What are the strategies that multinational companies can use to avoid taxes?

What are the weaknesses that could be identified in the Sri Lankan tax system and how can Sri Lanka improve its tax system about tax avoidance? The objectives of this study are to find tax avoidance strategies that can be used by multinational companies and to find improvements for the Sri Lankan tax system based on the loopholes that could be exploited by multinational companies.

\section{LITERATURE REVIEW}

A tax system could be described as a set of taxes in force in a country at a given period of time. The system implies the harmony between taxes and fiscal and extra fiscal objectives of the state (Collosa, 2017).

According to Fisher (2014), tax avoidance generally means reducing the tax payments legally. It is the behaviour of the taxpayer to reduce the tax liability and be prepared to completely disclose to the Inland Revenue Services. Tax avoidance practice could be implemented to accomplish one of the three reasons: to pay lesser taxes than required by the reasonable interpretation of the country's laws, payment of a tax on profits in one country rather than the country these were earned or make a late payment of taxes than these were earned. Those who are engaged in tax avoidance, are said to attempt to exploit the opportunities of uncertainty with regard to the doubts of applicable tax laws.

The scale of tax avoidance has grown on a very large scale such that currently it could be considered as a shadow economy. This situation is observable in most of the globalized markets such as banking and finance, communication, extractive industries, pharmaceuticals, weapons and media. Due to the secretive nature of the transactions, it is challenging to accurately estimate the size of the shadow economy. Some of the important findings were that although half of the world trade appears to pass through tax havens, these jurisdictions count only for $3 \%$ of the world gross domestic product (GDP). Approximately $60 \%$ of the international trade consists of intra-company transactions and these are passed through tax havens according to UK government estimates. By 2003, the International Monetary Fund (IMF) has identified more than 60 tax havens and offshore financial centres etc (Christensen and Murphy, 2004).

Considering the tax avoidance strategies of Multinational Companies (MNCs), tax inversion was identified as a major strategy (Contractor, 2016; Barker, Asere \& Brickman, 2017). This involves/ This is about shifting the corporate headquarters from a higher tax region with a merger of a firm in a lower tax jurisdiction (Contractor, 2016).

Barker, Asere \& Brickman (2017) have discussed transfer pricing in detail. U.S. corporations use transfer pricing as a vehicle to shift the income to countries with lower tax rates to reduce their effective tax rates. Although arm's length pricing principles are 
introduced, MNCs will exploit the flexibilities in the tax system to employ transfer pricing and other tax avoidance strategies. Contractor (2016) has discussed difficulties in imposing arm's length prices when there are intermediate goods, unique products or uniquely owned technologies.

Further, Contractor (2016) has found MNCs exploit royalty payment strategies to avoid taxes. Most of the MNCs are technologically intensive and most of their value includes these proprietary technologies or intangible assets. Transfer of the patents or brands to a subsidiary in a low tax regime or a shell company in a zero-tax regime in which the royalties could be charged for the headquarters and other affiliates was identified. Or else the royalty payments could be simply transferred to a shell company in Bermuda or the Cayman Islands despite the fact that Research \& Development (R\&D) is performed in another nation. Tax deductions for royalty payments could be obtained by the licensee even if the R\&D has not been performed in the licensee's nation. Moreover, Barker, Asere \& Brickman (2017) have discussed on R\&D of intangible assets with regard to tax avoidance.

Manipulation of debt based on the location is also considered as a strategy (Johansson et al., 2017; Contractor, 2016). Enforcement rules with regards to intra-corporate loans are found to be lacking especially in developing countries (Contractor, 2016).

Barker, Asere \& Brickman (2017) have disclosed the cost sharing agreements. Tax rates of the countries could also be a major consideration in sharing the parent overhead costs and other costs (Contractor, 2016).

Johansson et al. (2017) have also researched the use of hybrid instruments and transfers. There could be instruments that are considered and thus treated differently in two different countries as debt in one country and equity in another country. Accordingly, it would be interest deductible in the first country and tax exempted income in the second country. Hybrid entities were also considered with regard to tax avoidance strategies.

It is required to understand the loopholes of the Sri Lankan tax system since it is the base that needs to be treated to reduce tax avoidance. Accordingly, ad hoc changes to the tax system to meet short term cash flow requirements and the changes made to the tax incentives, concessions, holidays etc., negatively affect tax revenue in Sri Lanka. Furthermore, narrow tax base, the existence of a large informal economy, complications in the tax system along with weaknesses in the tax administration as well as granting of periodic tax amenities that would be ineffective were identified as reasons for the declining trend of Sri Lanka's tax revenue by Waidyasekera (2016).

There are many reasons for tax avoidance and tax evasion. Low tax morale, high compliance costs and specifically, taxpayers' endeavours to reduce the tax bill and increase profits could also be reasons. Accordingly, as there is not just one type of tax avoidance or tax evasion, there are many solutions that could be mastered for the type of 
tax avoidance or evasion as practiced by many developing countries which could also be adopted for the Sri Lankan tax system.

An effective strategy needs to address the root causes of the issue. If the absorptive capacity of the country is less, extensive capacity development initiatives should be implemented. Thereby, Sri Lanka could implement measures to improve tax compliance with taxpayer education and taxpayer service, addressing tax compliance costs and administrative costs as well as being service oriented. Measures could be implemented to improve the ability to enforce tax laws while addressing weak enforcement at the national level. As Kenyan experience reveals, it is easy to focus on a small group of crucial tax taxpayers which will simplify the enforcement of tax laws and reduce tax compliance costs. Accordingly, they formed a large taxpayer office as a one-stop service in 1998. Ghana has established a similar office in 2004 and was able to increase the tax revenue by $86 \%$ during $2003-2005$ (GIZ, 2010).

\section{METHODOLOGY}

A critical analysis is performed based on literature and secondary data from the reports. Reports included "A Step-by-Step Guide to Doing Business in Sri Lanka” by the Central Bank of Sri Lanka (CBSL), "Sri Lanka tax Profile" and "Handbook on Doing Business in Sri Lanka" by KPMG International Cooperative, "Doing Business" report by the World Bank group, and further reports published by European United Left/ Nordic Green Left a European parliamentary Group, Apple Inc., as well as Master thesis collected / accessed online.

The focus of this study would be mainly on the tax avoidance strategies of Apple Inc. A thorough analysis will be conducted on the strategies exploited by Apple Inc. on an empirical basis. Apple Inc. is a widely identified multinational company whose Effective Tax Rate is considerably lower than the Statutory Tax Rate. If a multinational company like Apple Inc. can avoid taxes whose origin is in the USA, where tax laws are considered to be stringent and strong, there is a higher possibility for other multinational companies to avoid taxes in other countries. Therefore, this paper aims to identify the loopholes in the Sri Lankan tax system and the ways to improve the Sri Lankan tax system based on the learnings acquired from the tax avoidance strategies extensively used by a multinational corporation like Apple Inc.

\section{RESULTS AND DISCUSSION}

Apple Inc. is a company that designs, manufactures and markets smartphones, personal computers, tablets, wearables and accessories, and sells a variety of relatable services. The company is a California corporation established in 1977. Tax avoidance strategies exploited by multinational companies discussed with the example of Apple Inc. could be identified as follows. (Apple Inc., 2019) 


\section{Financing structures and thin capitalization}

There are many ways that a company can finance its capital. Either a company could be completely equity, debt or a combination of debt and equity financing. Multinational companies (MNCs) attempt to select the most efficient capital structure to maximize the value of the company and to increase the bottom-line profits. According to Modigliani and Miller's (M\&M) theory, a geared business is more valuable due to the tax benefits that could be obtained with interest payments acting as a tax shield. The cost of geared equity will increase with high level of debt, but at a lesser level due to the tax benefits. Weighted Average Cost of Capital (WACC) is expected to drop as debt levels rise. Considering the above-mentioned theories, MNCs tend to make a financing decision that consists of a mixture of debt and equity because of the benefits that could be obtained through debt as mentioned above. However, the most beneficial level of debt and equity should be decided by the company through a thorough analysis to achieve the most efficient capital structure (Kaplan Financial Ltd., 2016).

MNCs are in a better position to obtain debt from another affiliate of the same company in another country. This process has the ability to reduce the overall tax liability by shifting debt from a lower to a higher tax regime. This is called "thin capitalisation" (Kaplan Financial Ltd., 2016). Accordingly, it was revealed that the debt to asset ratios in many MNCs are higher (Huizinga et al. and Egger et al., cited in Anggraeni, 2015). In some countries, corporate laws allow companies to be thinly capitalized or loaded with debt. However, the revenue authorities in these countries will be concerned about the amount of interest that a company can claim for tax deduction purposes, especially when a company receives loans at a non-commercial rate from a related party (McClure, Lanis and Govendir, 2016). This is because there is a possibility for the multinationals to lend for the related companies in higher tax jurisdictions at a higher interest rate than the commercial rates, thereby reducing the tax liability.

According to Apple Inc., there has been a high outflow of capital from Irish subsidiaries to Jersey subsidiaries in the form of expenditure on Intellectual Property and debt, where the interest deductions were $100 \%$ on these intra-firm debts (Christensen and Clancy, 2018). There are no thin capitalization rules in Irish tax law. Therefore, there is a higher possibility to reduce the overall tax bill by arranging the debt structure with the use of Ireland as a central point.

\section{Royalty payments}

Multinationals can avoid taxes through manipulation of royalty payments between the companies. This has been possible due to the three salient features. First, most of the MNCs are technology-intensive, so most of their values reside in the technologies or intangible assets. Second, with the current rules, the MNCs can transfer patents or brands to a holding company or a subsidiary in a low tax regime (such as Ireland) or a shellcompany (in a zero-tax regime like Bermuda) even if the R\&D costs are incurred in the 
home country. Then, the royalties could be charged for the parent company and other foreign affiliates. Third, most governments will allow tax deductions for the royalty payments when the licensee is part of the same MNC and even if R\&D costs have not been incurred in the licensee's nation based on the specific country rules and regulations. This will reduce the tax liability for the licensee. It would be highly beneficial for the multinationals to transfer the patents to shell companies established in the Cayman Islands or Bermuda just as how Google, Apple and many pharmaceutical companies have done such that the royalties are collected at zero tax liability even when the R\&D costs are incurred in another country (Contractor, 2016).

According to Apple Inc., although a major portion of the R\&D expenses is incurred in the headquartered U.S., the company reports a major portion of the R\&D in Ireland, so that a higher proportion of the revenue could be channelled through higher royalty payments (Fernandez and Hendrikse, 2015). Only a 3\% tax is applicable for the R\&D activities in Ireland. Further, there's a 100\% cap on the capital allowance which could be claimed for IP expenditure. Although this was reduced to $80 \%$ in 2017 , the regulation would not be applicable for the IP rights that were brought from 2015-2017 (Christensen and Clancy, 2018). Accordingly, Apple Inc.'s IP rights that were brought during 20152017 got the $100 \%$ capital allowance.

\section{Double Irish Arrangement and Dutch Sandwich}

Under the Double Irish Arrangement, various definitions of corporate residency of different countries are exploited, particularly with regard to Ireland and the U.S.A. Ireland charges taxes on companies if they are managed and controlled in Ireland, whereas the U.S charges taxes on companies based on where a corporation is registered (Anggraeni, 2015). However, in 2014 with the international pressures, Ireland has changed the regulation such that all the companies registered in Ireland require to be tax residents as well. Existing companies would have had a transition period till the end of 2020. New companies would have had time till the end of January 2015 to change their structure so as to use the Double Irish system legally till the end of the transition period. However, there's a provision for 'management \& control' test with several treaties. If a company is a resident in both Ireland and another country that has a treaty with, tax residency will be determined based on the management $\&$ control rule. Accordingly, if the tax treaty partner is a low or zero tax jurisdiction it will provide a platform for tax avoidance through Double Irish arrangement (Christensen and Clancy, 2018).

For the Double Irish Arrangement, a pair of Irish companies will be required. Precisely, the U.S. parent company will create two Irish subsidiaries, one to hold the Intellectual Property (IP) and the other for operations. The U.S. parent company will allow the European rights to the IP holding company through a contract. The other Irish subsidiary will market the products in Europe and other jurisdictions except for the U.S. Thus, all the income from the IPs would be taxed in Ireland which would have been otherwise 
taxed in the U.S. Then the Irish subsidiary changes the headquarters to a tax haven like Bermuda which will be controlled and managed in Bermuda. As Ireland determines tax based on the control and management of the corporation, they believe that the company will be taxed in Bermuda and similarly, the U.S believes that the company will be taxed in Ireland since the company has been incorporated in Ireland. Thereby, actually, the multinational will not be taxed in any of the jurisdictions with this arrangement (Anggraeni, 2015).

IP Holding companies can license the IP rights to the operating company for license fees and royalties which are not determined for tax purposes under U.S tax laws. Although the Operating company earns an income from the use of assets outside the U.S., the taxable income will be low due to the higher royalty payments or license fees incurred for the IP Holding company and that these expenses are tax deductible. Royalty payments received by the IP Holding company will not be taxed in Ireland or U.S until these are transferred to the U.S under the conditions mentioned below (Anggraeni, 2015).

According to U.S. corporate taxation, U.S. companies are taxed up to $35 \%$ on their worldwide income. Passive income earned by a foreign affiliate such as royalties, dividends and interest etc., is subject to taxes regardless of whether they are repatriated to the U.S. This is mainly imposed to reduce the tax avoidance by multinationals through the Double Irish Arrangement as mentioned above. However, this could be bypassed with a few possibilities. There is an exception when manufacturing is carried out by the same foreign subsidiary. Another fact is that the passive income taxation will be applicable only if the company is sufficiently controlled by the U.S. nationals or residents according to their definition of $50 \%$ or more ownership by U.S. nationals with at least $10 \%$ ownership in the foreign corporation. Further, under the laws related to Deferred Tax Liabilities on Permanently or Indefinitely Invested Foreign Earnings, it should be sufficiently proven that the foreign income of the subsidiary has invested or will invest the undistributed earnings indefinitely with evidence of specific plans for reinvestment. If the above-mentioned conditions could be sufficiently exploited by a U.S. company, taxes could be possibly avoided by practicing the above-mentioned strategies and arrangements. (Anggraeni, 2015)

Double Irish Arrangement would be further effective if it is integrated with the "Dutch Sandwich". In this scenario, the U.S parent company will establish another conduit subsidiary in a country like the Netherlands. Accordingly, the transfers between the two Irish companies will take place through this subsidiary (a shell company) in the Netherlands where the tax rates are even low, which is applicable only for the use of the Dutch tax system. Within the arrangement, IP Holding company will be the single owner of the Conduit subsidiary and the Operating company. The royalty payments will then be transferred from the Operating company to the Conduit company then directly transferred to the IP Holding company. This will reduce the Irish withholding tax on royalty payments which would have been otherwise transferred from the Operating company to 
the IP Holding company in Bermuda. With the use of the Double Irish Dutch Sandwich withholding taxes on royalty payments could be completely avoided since the royalties paid from Ireland to the Netherlands are tax free under the EU Royalty and Interest Directive and the Netherlands do not impose withholding taxes on royalty payments regardless of the state of the receiving company (Anggraeni, 2015).

The process of Double Irish Arrangement could be depicted as in the Figure 1.

Figure 1: Process of Double Irish Arrangement with Dutch Sandwich

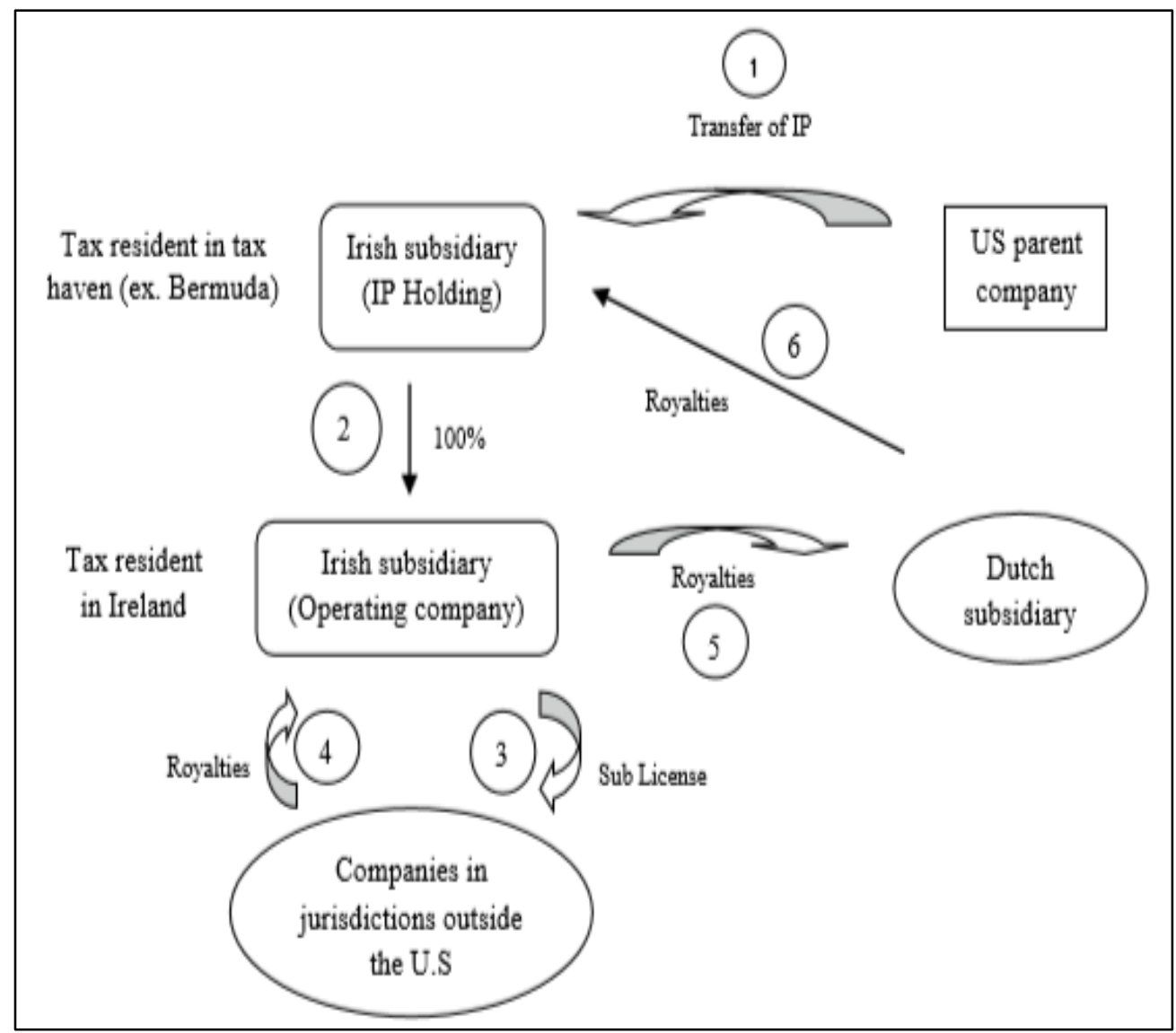

Source: Anggraeni (2015)

The exploitation of this method could be identified with Apple Inc. The company organized a new structure in 2015 with the change of the regulations of Ireland in 2014 which included, relocation of non-U.S. sales and much of its IP to Ireland and relocation of its overseas cash to Jersey as depicted in Figure 2 with a further comparison of Apple Inc's pre-2015 corporate structure as depicted in Figure 3. According to Orbis, Apple Inc. has a subsidiary in the Cayman Islands as Xiaoju Kuaizhi Inc. which owns 43 subsidiaries across most of the world. However, it was not to be found in the Cayman Islands Company Register (Fernandez and Hendrikse, 2015). 
Figure 2: Apple Inc.'s Offshore Organogram (Post 2014 Corporate Structure)

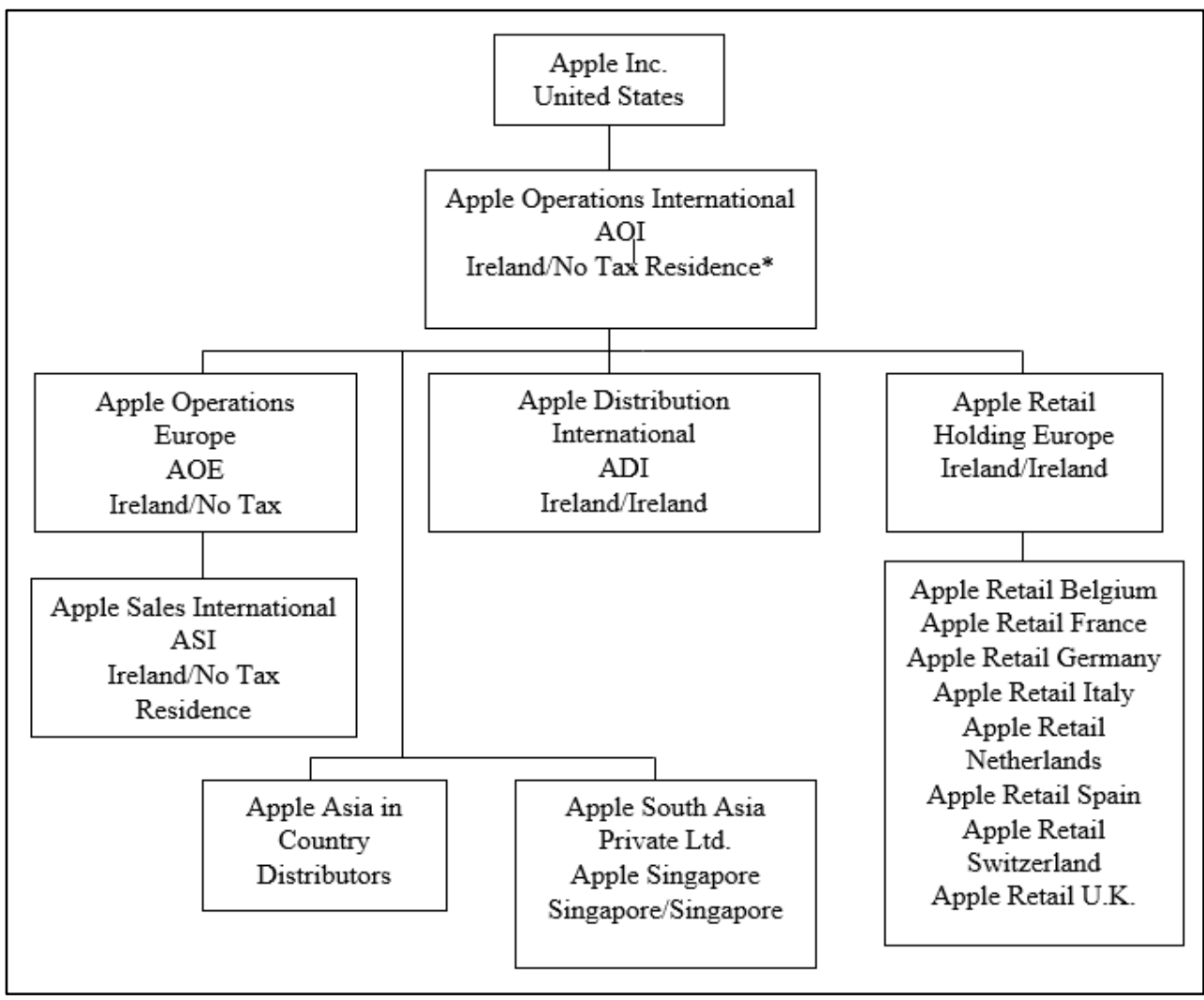

Source: Fernandez and Hendrikse (2015)

Figure 3: Apple Inc.’s Pre-2015 Corporate Structure

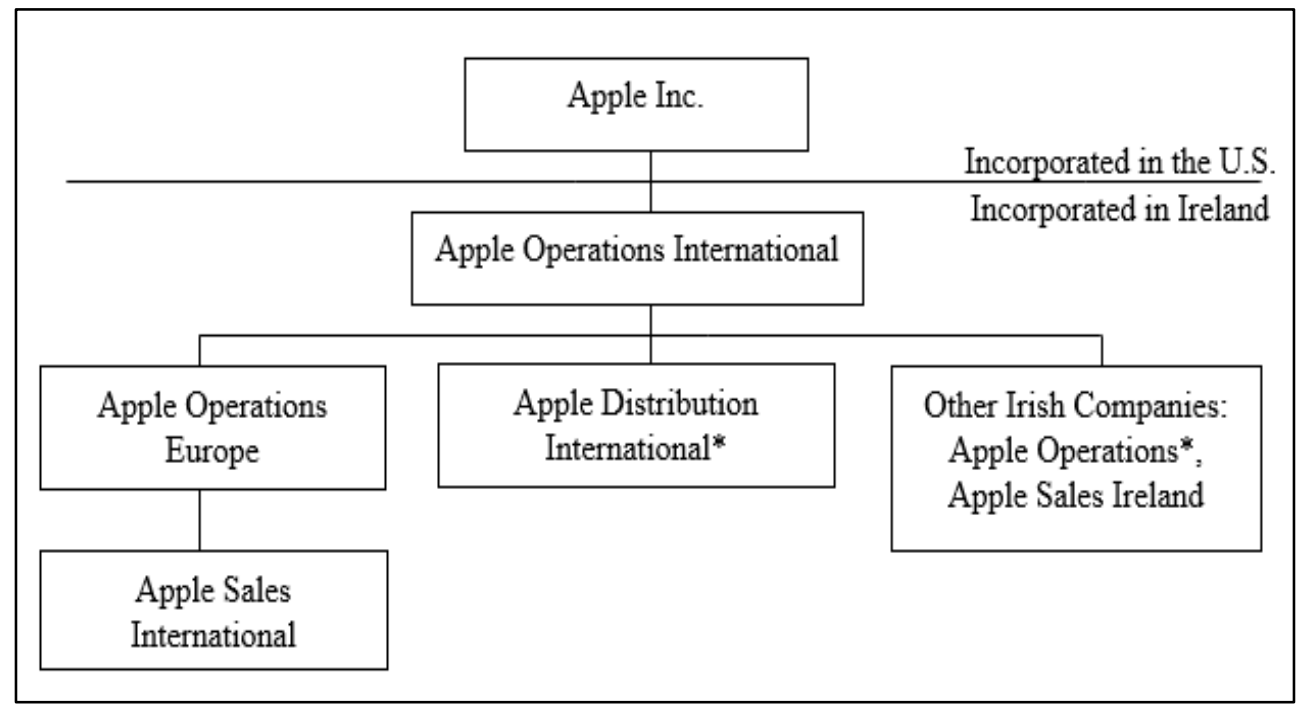

Source: Christensen and Clancy (2018) 
This could be further identified with the provision for income taxes and effective tax rates over the years given in Table 01 .

Table 01: Provision of Income Tax and Effective Tax Rates

\begin{tabular}{lrrrrr}
\hline Year & $\mathbf{2 0 1 9}$ & $\mathbf{2 0 1 8}$ & $\mathbf{2 0 1 7}$ & $\mathbf{2 0 1 6}$ & $\mathbf{2 0 1 5}$ \\
\hline Income taxes (\$ in millions) & 10,481 & 13,372 & 15,738 & 15,685 & 19,121 \\
Effective tax rate & $15.9 \%$ & $18.3 \%$ & $24.6 \%$ & $25.6 \%$ & $26.4 \%$ \\
Statutory federal income tax rate & $21.0 \%$ & $24.5 \%$ & $35 \%$ & $35 \%$ & $35 \%$ \\
\hline
\end{tabular}

Source: Apple Inc. (2019); Apple Inc. (2017)

As illustrated in the above table, the company's effective tax rates for the period considered have been different from the statutory federal income tax rate. For the period from 2015-2017, this has been mainly due to the undistributed foreign earnings. A major portion of these earnings is generated by the subsidiaries in Ireland. There will be no US taxes charged on these foreign earnings if they are shown to be indefinitely reinvested outside the US. (Apple Inc., 2017).

\section{Chains of ownership}

There are two main methods that taxes could be avoided through chains of ownership. One way is that the profits of the foreign subsidiaries are reinvested in equity of another existing foreign subsidiary which will replace or add to the original equity from the parent, rather than repatriated to the parent company. This is called the "Triangular Strategy", since the earnings of a foreign subsidiary are channelled to the parent company and another foreign affiliate (Anggraeni, 2015).

The second strategy is to use the retained earnings of a foreign affiliate to capitalize on an initial investment of another foreign subsidiary (Anggraeni, 2015).

Structure of the Apple Inc.'s operations could be observed in several tiers as depicted in Figures 2 and 3 above. Apple Operations International (AOI) is fully owned by the mother company in Cupertino. It doesn't have any employees, but its assets are managed by another subsidiary, Braeburn Capital in Reno, in the state of Nevada where the corporate taxation is at $0 \%$ while the assets are held in the bank accounts of New York (Fernandez \& Hendrikse, 2015).

\section{Cost sharing agreements}

According to Apple Inc. component manufacturing is outsourced for companies around the world, especially for low-cost bases. Assembly of finished products is outsourced to 
a small set of assembly specializers. Foxconn International Holdings is the largest outsourced company, which is domiciled in the Cayman Islands, listed on the Hong Kong stock exchange and operates in China (Fernandez \& Hendrikse, 2015). When the costs are shifted to low-cost bases, the overall profits of the company will increase.

\section{Identifying and addressing the loopholes of the Sri Lankan tax system}

It has been identified that Sri Lanka has experienced a fiscal deficit for a long time. The country was not able to raise its tax revenue significantly as a percentage of the GDP. Accordingly, one main issue identified in Sri Lankan taxation is the low level of tax ratio. It was clearly identified that the country heavily depends on indirect taxes and that will have a wider impact on the general public than direct taxes. The behavioural pattern of transforming the tax revenue generation of developed countries is that indirect taxes reduce gradually, and the direct taxes consist of a wider proportion. It has been identified that the decline in tax ratio in Sri Lanka is mostly due to the decline in indirect taxes. The country has been unable to increase the direct taxes to offset the decline of indirect taxes. (Amirthalingam, 2013)

Waidyasekera (2016) has studied the reasons for the decline of tax revenue of Sri Lanka despite the increase in GDP. As noted previously, the reasons could be illustrated as an increase in allowable tax expenses under Section 25 of the Inland Revenue Act, ad hoc changes to the tax system to meet short term cash flow requirements and the changes made to the tax incentives, concessions, holidays etc., narrow tax base, the existence of a large informal economy, complications in the tax system along with weaknesses in the tax administration as well as granting of periodic tax amenities that would be ineffective at the end. It could be clearly understood that the increase of the allowable tax expenses, the existence of a large informal economy along weak tax administration that have complications in the tax system would be major junctures to be used by the multinational companies to avoid taxes.

The tax system could be improved by identifying and addressing the loopholes of the tax system, weaknesses of the tax administration authorities and addressing any exogenous factors that may negatively influence the efficacy of the whole process. Therefore, ways to improve the Sri Lankan tax system based on the learnings acquired from the above section with the identification of loopholes of the Sri Lankan tax system and the relevant environment could be illustrated as follows.

Sri Lanka has not yet paid sufficient attention to country-by-country reporting. However, it is of greater importance to identify the company structures and their plans for any use of tax avoidance strategies. This will help to identify Controlled Financial Corporations (CFC), any games played with transfer pricing, dividends, debt and interest, profit shifting or earnings stripping etc. Accordingly, country-by-country reporting should be implemented, especially for the foreign companies where headquarter is positioned or repositioned in Sri Lanka. 
Under the rules for transfer pricing in Sri Lanka, a common reporting standard has gained a lack of attention over the years. This could be implemented with the guidelines /studies of International Accounting Standards and the reporting standards of other countries. The importance of a common reporting standard was identified worldwide which makes the administration process more convenient and to easily identify the use of tax avoidance strategies by multinational companies.

Certain incentives to be limited include the tightening of rules for foreign dividend income. One situation is where the companies engaged in R\&D are entitled to $100 \%$ tax deduction of the total value of R\&D expenses (KPMG, 2018b). Certain multinational companies could incur research costs in Sri Lanka to benefit from the incentives and patent in another country of operations, probably in a tax haven where the royalty payments could be earned at a little or no tax rate just as how companies like Apple Inc. has done. Accordingly, if the companies are engaged in research activities, the Inland Revenue Department or the Board of Investments needs to monitor the progress of the activities and guide the same to necessarily register that product within the country itself. This should also be facilitated with strong rules of law on patent rights, enforcing contracts, institutional strength etc.

Another situation is a capital allowance of $150 \%$ granted for the investments made on the assets worth greater than US\$250 Mn or in shares of state-owned companies (KPMG, $2018 \mathrm{~b})$. Three issues could be observed within this incentive. Since the $150 \%$ tax concession is comparatively excessive, foreign companies may bring in the money to the country to shift their profits and reduce the overall tax bill. Another issue is that once the foreign companies invest in shares of state-owned companies, the growth benefits of the country could be yielded by the foreign entities in future whereas they get to influence the important government matters.

Further, investments could be brought in terms of dividends through a resident company. Dividend income received by a resident company from an offshore affiliate is exempted from taxes based on the condition that the resident shareholder has a substantial participation in the non-resident company. Substantial participation is defined as having $10 \%$ or more of the shares of the non-resident company (excluding redeemable shares) and control of $10 \%$ or more of the company directly or indirectly) by the shareholder (KPMG, 2018b). If the dividends received are exempted from taxes with the entitlement to the above condition, multinational companies could consider it as a loophole to structure their company so as to shift profits and reduce the tax bill.

Since there are several tax incentives available within the country in terms of capital allowances, MNCs have the ability to reduce the tax bill by routing the money in terms of dividend income and investing them in assets or shares of a company which will have allowances up to $200 \%$ depending on the criteria of the investment. Thereby, companies can reduce the tax bill by two strategies in this context. 
Accordingly, this risk could be reduced by increasing the minimum ownership stake of $10 \%$ which could also be done with the improvement of the CFC rules. Moreover, the capital allowance could also be reduced.

\section{Formulation and implementation of Controlled Financial Corporation (CFC) rules}

It was identified that $\mathrm{CFC}$ rules have not been within the major focus of the Sri Lankan tax authorities (KPMG, 2018a). Generally, CFC rules are applicable for the foreign companies which are sufficiently controlled or have sufficient power to influence the company by the shareholders of the parent jurisdiction where the foreign companies have meaningfully lower effective tax rates than the parent jurisdiction. These rules also provide recommendations to bring the non-corporate entities and income within the CFC rules (OECD, 2015). Accordingly, given the low tax ratios of the country, formulation and implementation of CFC rules are of higher importance given that even the other developing countries of the region like India have already implemented them. These rules will act as a deterrent for tax deferral and profit shifting to foreign subsidiaries.

Further, the following suggestions could be made to improve the Sri Lankan tax system with the identification of the weaknesses in general.

Ad hoc changes made to the tax system should be minimized to meet the short terms cash flow requirements. One main strategy that could be used by multinational companies is to exploit any differences in the definitions and tax treatments of the countries. The higher the ad-hoc changes made; the higher will be the loopholes that could be exploited.

During the process of the registration of a foreign company in Sri Lanka, the particular company has to separately register in the Company Registrar, the Board of Investments and the Inland Revenue Department (Central Bank of Sri Lanka, 2018). Tax avoidance of multinational companies could be minimized to a greater extent if there is a strong technical network between the government institutions, such that the companies could be easily tracked with improved access to a common information system. Institutions should look for the possibility to maintain a common identification number apart from the different identification numbers that each institution maintains for the customers to support the integrated system. Although this process would be costly, such an investment would yield immense benefits in future.

It is required to constantly educate the tax administration staff with regard to the tax avoidance strategies used by multinational firms. The research unit of the authorities should be improved to identify new strategies. The implementation of country-by-country reporting and the establishment of a common reporting standard will also affect the efficiency of the authorities.

When analysing the legal system with regard to tax avoidance, a strong system could be identified where rules have been formulated for most of the strategies used by the advanced MNCs in the world. For example, in thin capitalization rules, debt cannot 
exceed 3 times the equity for manufacturers and 4 times the equity for others (KPMG, 2018 b). Although the companies try to overload debt for a country to exploit the benefit that could be gained due to the different interest rates, similar games may not be played to the same extent in Sri Lanka with the restrictions imposed on gearing ratios. Therefore, the improvement of the rule of law has a major role to play. Reducing the corruption and political interference and automation of the process will enhance the rule of law further. Sri Lanka has already started with online filing of corporate tax, VAT and ETF which is a step forward (World Bank, 2019).

\section{CONCLUSION AND POLICY RECOMMENDATIONS}

The study identified the importance of understanding the strategies exploited by MNCs to avoid taxes. Accordingly, some of the strategies identified were exploiting financing structures and thin capitalization, royalty payments, Double Irish Arrangement and Dutch Sandwich, chains of ownership and cost sharing agreements. The identified strategies were analysed with Apple Inc. Accordingly, how Sri Lanka could improve its tax system with the identification of loopholes of the Sri Lankan tax system and the relevant environment was also analysed based on the strategies that could be exploited by the multinational companies to avoid taxes.

Thus, it is of utmost importance to address the loopholes of the legal system by implementing country by country reporting, a common reporting standard for all the companies, certain incentives to be limited including the tightening of rules for foreign dividend income and formulation and implementation of CFC rules. Further, it was recommended to address the ad-hoc changes made to the system, a strong technical network to be established between the government institutions, improve the strength and capacities of tax investigation authorities, and improve the rule of law.

\section{REFERENCES}

Amirthalingam, K. (2013). Importance and Issues of Taxation in Sri Lanka. Colombo Business Journal, 4(1), University of Colombo.

Anggraeni, S. (2015). Money Moves: Tax Planning in Multinational Companies: A Case of Microsoft, Masters' thesis, Norwegian School of Economics.

Apple Inc. (2017). Form 10-K. United States Securities and Exchange Commission, https://www.annualreports.com/HostedData/AnnualReportArchive/a/NASDAQ AAPL 2017.pdf

Apple Inc. (2019). Form 10-K. United States Securities and Exchange Commission, https://s2.q4cdn.com/470004039/files/doc financials/2019/ar/ 10-K-2019-(AsFiled).pdf 
Barker, J., Asare, K., \& Brickman, S. (2017). Transfer Pricing as A Vehicle in Corporate Tax Avoidance. Journal Of Applied Business Research, 33(1), 9-16. https://doi.org/10.19030/jabr.v33i1.9863

Central Bank of Sri Lanka. (2018). A Step-by-Step Guide to Doing Business in Sri Lanka, 2nd ed., pp. 1-153. Central Bank of Sri Lanka.

Christensen, J., \& Murphy, R. (2004). The Social Irresponsibility of Corporate Tax Avoidance: Taking CSR to the bottom line. Development, 47(3), 37-44. https://doi.org/10.1057/palgrave.development.1100066

Christensen, M., \& Clancy, E. (2018). Exposed: Apples's Golden Delicious Tax Deals, European United Left - Nordic Green Left European Parliamentary Group. Retrieved from https://left.eu/content/uploads/2018/06/Apple_report final.pdf

Collosa, A. (2017). Tax Systems and Tax Reforms. Some ideas on the topic. Ciat.org. Retrieved on 27 September 2021, from https://ciat.org/sistemas-tributarios-yreformas-tributarias-algunas-ideas-del-tema-parte-1/?lang=en

Contractor, F. (2016). Tax Avoidance by Multinational Companies: Methods, Policies, and Ethics. AIB Insights, 1(1), 27-43. https://doi.org/10.46697/001c.16887

Dharmarathna, D. (2020). Corporate Tax Planning and Financial Performance of Companies Listed in Colombo Stock Exchange (CSE). Applied Research Journal of Humanities And Social Sciences, 3(2), 1-15.

https://doi.org/10.47721/arjhss202002045

Fernandez, R., \& Hendrikse, R. (2015). Rich Corporations, Poor Societies: The Financialisation of Apple. Good Electronics \& SOMO. Retrieved on 26 September 2021 from https://www.somo.nl/wp-content/uploads/2015/10/Rich-corporationspoor-societies.pdf

Fisher, J. (2014). Fairer Shores: Tax Heavens, Tax Avoidance and Corporate Social Responsibility. Boston University Law Review, 94(337), 337-365.

GIZ (2010). Addressing Tax Evasion and Tax Avoidance in Developing Countries. Information and Communication Technologies for Development. GTZ.

Johansson, Å., Skeie, Ø., Sorbe, S., \& Menon, C. (2017). Tax Planning by Multinational Firms: Firm Level Evidence from a Cross Country Database. Organisation for Economic Co-operation and Development. Retrieved on 26 September 2021, from https://www.oecd.org/economy/public-finance/Tax-planning-by-multinationalfirms-firm-level-evidence-from-a-cross-country-database.pdf

Kaplan Financial Ltd. (2016). Cima F3 Financial Strategy - Study Text. Kaplan Publishing. 
KPMG in Sri Lanka. (2018a). Handbook on Doing Business in Sri Lanka: Prepared for the Embassy of the Kingdom of the Netherlands by KPMG in Sri Lanka, Netherlands Enterprise Agency. Retrieved 27 September 2021, from https:/www.rvo.nl/sites/default/files/2018/06/Investment-Handbook-Sri-

\section{Lanka.pdf}

KPMG. (2018b). Sri Lanka Tax Profile. KPMG International Cooperative. Retrieved on 27 September 2021, from

https:/home.kpmg/content/dam/kpmg/xx/pdf/2018/09/sri-lanka-2018.pdf

McClure, R., Lanis, R., \& Govendir, B. (2016). Analysis of Tax Avoidance Strategies of Top Foreign Multinationals Operating in Australia: An Expose. University of Technology: Sydney.

OECD (2015). Designing Effective Controlled Foreign Company Rules. Action 3: 2015 Final Report. OECD.

Rego, S. (2003). Tax-Avoidance Activities of U.S. Multinational Corporations. Contemporary Accounting Research, 20(4), 805-833.

https://doi.org/10.1506/vann-b7ub-gmfa-9e6w

Waidyasekera, D. (2016). Taxation in Sri Lanka: Current Trends and Perspectives. Institute of Policy Studies of Sri Lanka.

World Bank (2019). Doing Business 2019. World Bank Group. Retrieved from https://www.doingbusiness.org/content/dam/doingBusiness/media/AnnualReports/English/DB2019-report_web-version.pdf 